Accepted refereed manuscript of: de la Caba K, Guerrero P, Trung TS, Cruz M, Kerry JP, Fluhr J, Maurer M, Kruijssen F, Albalat

A, Bunting S, Burt S, Little D \& Newton R (2018) From seafood waste to active seafood packaging: An emerging opportunity of the circular economy. Journal of Cleaner Production, 208, pp. 86-98. https://doi.org/10.1016/j.jclepro.2018.09.164

(C) 2018,Flsevier Licensed under the_Creative Commons Attribution-NonCommercial-NoDerivatives 4.0 International http://

creativecommons.org/licenses/by-nc-nd/4.0/

From seafood waste to active seafood packaging: An emerging opportunity of

\title{
the circular economy
}

Koro de la Caba ${ }^{1}$, Pedro Guerrero ${ }^{1}$, Trang Si Trung ${ }^{2}$, Malco Cruz-Romero ${ }^{3}$, Joseph P

Kerry $^{3}$, Joachim Fluhr ${ }^{4}$, Marcus Maurer ${ }^{4}$, Froukje Kruijssen ${ }^{5}$, Amaya Albalat ${ }^{6}$, Stuart

Bunting $^{6}$, Steve Burt ${ }^{7}$, Dave Little ${ }^{6}$, Richard Newton ${ }^{*}$

1 BIOMAT research group, University of the Basque Country (UPV/EHU), Escuela de Ingeniería de Gipuzkoa, Plaza de Europa 1, 20018 Donostia-San Sebastián, Spain

2 Nha Trang University, 02 Nguyen Dinh Chieu, Nha Trang, Vietnam

3 Food Packaging Group, School of Food and Nutritional Sciences, College of

Science, Engineering and Food Science, University College Cork, Ireland

4 Allergie-Centrum-Charité, Department of Dermatology and Allergy, Charité

Universitätsmedizin Berlin, Charitéplatz 1, 10117 Berlin, Germany

5 Royal Tropical Institute, Sustainable Economic Development \& Gender Unit,

Mauritskade 64, 1092AD Amsterdam, The Netherlands

6 Institute of Aquaculture, University of Stirling, Stirling, FK9 4LA, UK

7 Stirling Management School, University of Stirling, FK9 4LA, UK

* Corresponding author

e-mail: richard.newton@stir.ac.uk

\section{Abstract}

Sustainable development is an overarching objective that requires an interdisciplinary approach in order to address the societal challenge concerning climate action, 
environment, resource efficiency and raw materials. In this context, valorization of abundant and available bio-wastes with high potential to manufacture value-added products is the first step to close the loop between waste and consumption in line with the main goal of the circular economy. In the last years, many research works have been published in the literature regarding novel food packaging. However, most of them are focused on packaging composition (scientific aspects) and some of them on the packaging manufacture (technological aspects), but very few studies are concerned about the influence of bringing novel food packaging systems into the market on environmental, social and economic issues. In this regard, this review intends to fill this gap, considering the potential of developing food packaging from food processing waste in order to create business for food industries, being aware of the food quality demanded by consumers and the environmental care demanded by institutions and society.

Keywords: Waste valorization; Resource efficiency; Sustainable packaging; Interdisciplinary approach; Life Cycle Assessment; Circular Economy. 


\section{Introduction}

As populations have grown and the economies of both developed and developing countries have continued to mature, consumer demand has created a growing strain on resources. Consumers have also demanded greater safety, sustainability and responsibility on food production along with convenience and lifestyle considerations (Aschermann-Witzel et al., 2016; Simoes et al., 2015). Sustainable food production encompasses three main pillars; environmental, economic, and social.

These aspects are all required to maintain production in the long term without impacting on the wellbeing of societies, their surrounding environments (Bowen and Friel, 2012), and the health of the planet as a whole (Janssen et al., 2006). Therefore, innovation in food market requires a multi-scale, multi-disciplinary, and multi-factorial approach, involving initiatives from politicians, industries, researchers, and consumers, who all play a relevant role in the sustainability of the food chain (Fraser et al., 2016; Wikström et al., 2016). Although many governments place emphasis on local food production, food production around the globe is ever more dependent on the international flow of raw materials. Both better-off and poorer countries are dependent on food imports; the UK is just $60 \%$ food-self-sufficient and, according to Fader et al. (2013), at least 66 countries are not self-sufficient, with countries as diverse as Egypt and Bangladesh constrained by a lack of natural resources, such as land or water, to meet their food production needs. Some food sectors, such as monogastric livestock (pig, poultry, fish), are particularly dependent on imports of feed ingredients, notably soybean meal. Cradle-to-grave perspectives using tools such as global value chain analysis (GVCA) and life cycle assessment (LCA) are appropriate for the investigation of food production practices, which also must incorporate the technical and economic realities of globalized food production (Laso et al., 2016).

As resources become more precious, governments have placed pressure on industries and individuals to adopt the "reduce, reuse, repair, and recycle" hierarchy of 
resource efficiency. This has more recently been adopted into the "circular economy" philosophy (Genovese et al., 2017). The essential principles of the circular economy are to reduce resource use and environmental emissions by "closing the loop" of production (Jurgilevich et al., 2016). According to Stahel (2016), there are two basic models for the circular economy: 1) where products at the end of their usable life are continually reused through repair and remodeling and 2) where materials are recycled to manufacture into replacement products. However, this ignores a third option where by-products and wastes from industries are utilized by related industries and may eventually be indirectly fed back into the original industry, which is more common in the food production sector (Fig. 1). Reuse of by-products within the sector is especially important in these related industries, as they are often in competition for similar resources, either directly, such as soybeans, or indirectly such as water and land for production of crops.

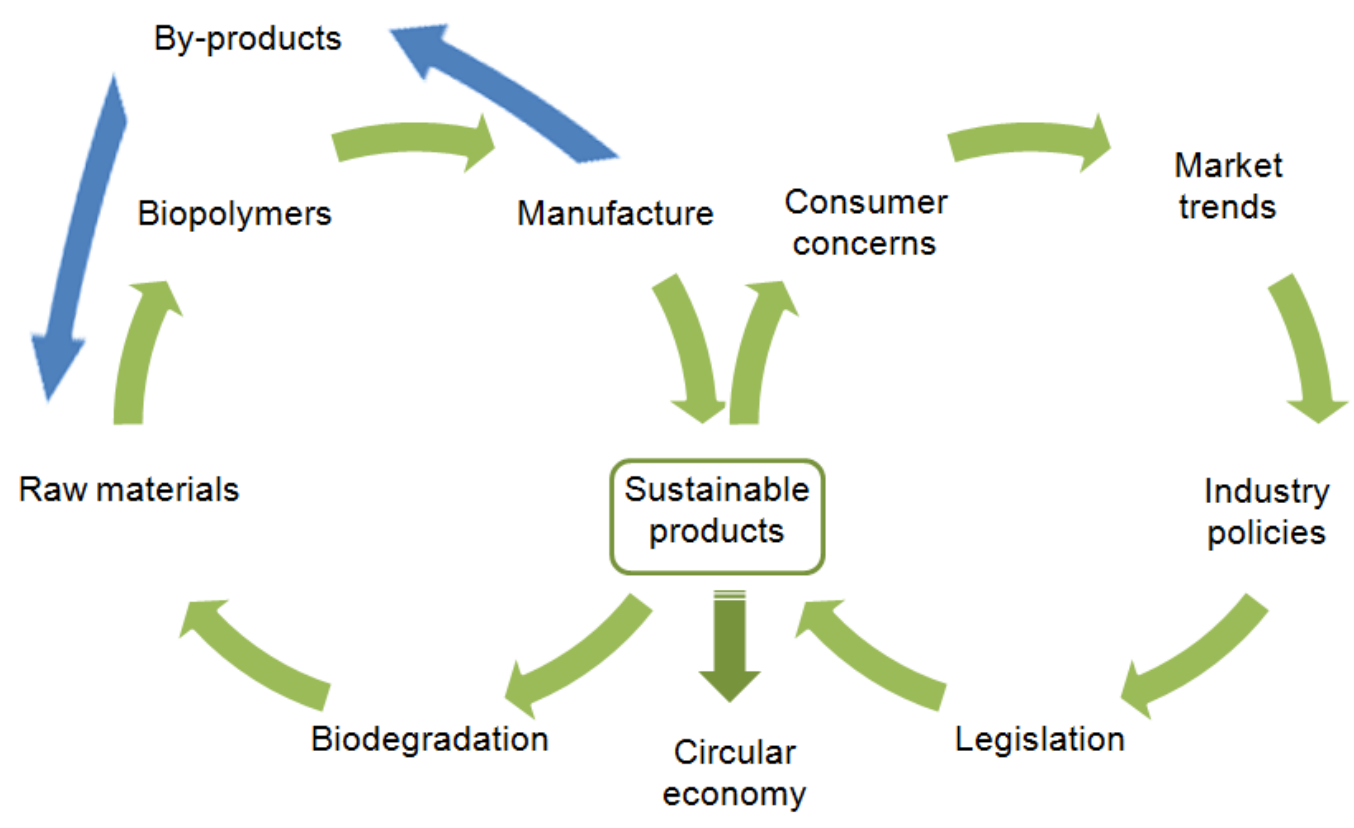

Fig.1. The inter- and multi-disciplinary approach addressed when researching packaging. 
Food processing and packaging are the most important parts of the food industry (Perrot et al., 2016). More processed and packaged food is consumed as a proportion of the total in better-off, urbanizing, and industrializing economies (Kearney, 2010). In the specific field of food packaging, there are some clear emergent trends with regard to the sourcing and use of raw materials. These changes are probably less related to any depletion of non-renewable resources, but rather to increased interest in addressing sustainability aspects related to both resource efficiency and waste disposal and treatment (Stahel, 2016). In this regard, governments, industries, and consumers are very much concerned about the impacts of the products consumed. Consumer interest in the sustainable production of foods and food-related issues is expected to be an increasing trend, and legislation is beginning to reinforce this trend towards "socially responsible products" (FAO 2015). Furthermore, the improvements in the development of renewable and biodegradable materials to achieve the properties required for food packaging applications have largely increased the business potential of this industrial sector, and the global demand for the food packaging market. In particular, active packaging, antioxidant and antimicrobial packaging for food shelf-life extension, is expected to grow at $6.0 \%$ to reach a value of approximately US\$29.0 billion by 2020 (Future Market Insights, 2017). In this context, materials science and technology are complementary to support improvements in food quality and safety from a sustainable point of view.

Fundamentally, any food packaging must contain, protect, preserve, inform, and provide convenience while acknowledging the constraints placed upon their usage from both legal and environmental perspectives (Kim and Seo, 2018). Additionally packaging technologies need to address consumer expectations for product quality (Wilson et al., 2018). In this regard, this highly inter-disciplinary review looks at how a circular economy principle can be applied to the seafood industry by utilizing food 
processing by-products in environmentally friendly active packaging solutions to reduce food spoilage, post-processing, and to extend shelf life.

In this review, the potential of food processing waste to be valorized by means of extracting biopolymers that could be used to extend food shelf-life will be revised. In this regard, the possible allergenic risk when using these raw materials will be considered. Additionally, the processing methods used to manufacture packaging as well as the functional properties required to develop antioxidant and antimicrobial packaging will be assessed. In addition to these scientific and technological issues concerning food packaging, environmental aspects will be taken into consideration, as well as socio-economic impacts, in order to develop more sustainable packaging systems.

\section{Methods and literature sources}

This review brings together a highly interdisciplinary team of experts in biotechnology, allergen research, environmental management, aquaculture sciences, consumer behavior, retail studies, social sciences and food policy. Each author has brought their experiences of years of research in their fields to identify and critique the most relevant and up-to-date literature appropriate to food packaging and the circular economy, as well as extensive searches in academic literature databases. The methodology followed a narrative review approach to give an overview of the key research areas and identify research gaps that would be necessary to address before adoption of this circular economy opportunity. The narrative approach fits with the objectives of an inter-disciplinary review in addressing a broader but interconnected scope of research (Ferrari, 2015). There were no specific time scale criteria for inclusion, because literature relevant to different disciplines had heterogeneous publication histories. As can be seen in Figure 2, the bulk of the literature relating to technical advances in packaging is the most up-to-date, falling within the last 5 years, 
whereas literature relating to food waste and environmental and social impacts is more wide-spread over the span of the review. However, some of the earliest references refer to early work on chitosan as an antimicrobial agent. It is worth noting that $80 \%$ of the articles studied were published in this decade, of which more than $50 \%$ correspond to papers published in the last five years (Figure 2). Scientific data bases, such as Web of Science, Scopus and Google Scholar, were used to search literature related to active packaging, food shelf-life, allergy, sustainability, waste, valorization, environmental impact, and circular economy, the principal keywords of this study. The information regarding these topics has been obtained mainly from original research papers, although some recent reports from international organizations have also been considered. In total, 111 peer-reviewed articles, 16 reports and 4 book chapters were analyzed. It is worth noting that $80 \%$ of the articles studied were published in this decade, of which more than $50 \%$ correspond to papers published in the last three years (Figure 2). Regarding the most recent literature, the relative increase of the number of works related to food waste and environmental issues is noticeable, in accordance with the consumers' and institutions' concerns on these topics.

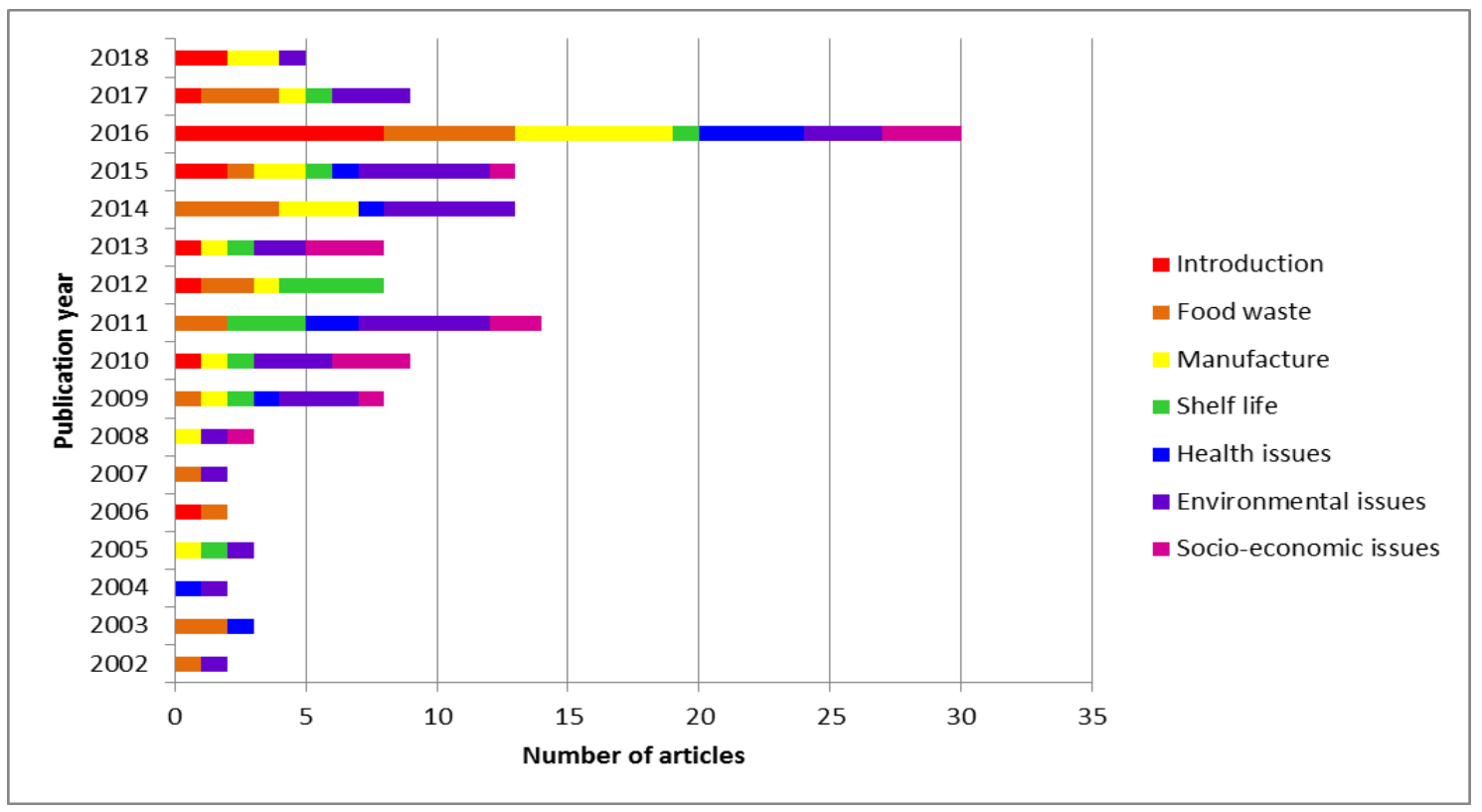

Fig.2. Distribution of the peer-reviewed papers analyzed by the publication year. The same articles may appear in more than one section. 
Information related to the development of active packaging from a global and sustainable point of view, considering all the aspects from the extraction of raw materials to the end of life of products, including economic, social, health and environmental concerns, was analyzed. The references cited are related to those issues, in particular, food loss reduction, resource efficiency, sustainability, and circular economy. The journals consulted belong to diverse inter-disciplinary subject areas such as Green and Sustainable Science and Technology, Environmental Engineering, Food Science and Technology, and Applied Chemistry (Table 1). The most relevant information from those sources was selected after reading the full text and analyzing the results discussion supported by the data shown in the research works. The data was compiled into an extensive and inclusive review covering all aspects of the circular economy for seafood packaging and edited by the authors. 
Table 1. List of the journals cited in each section more than once and their corresponding subject area.

\begin{tabular}{|c|c|c|c|c|}
\hline $\begin{array}{l}\text { Manuscript } \\
\text { section }\end{array}$ & $\begin{array}{l}\text { Total } \\
\text { references }\end{array}$ & $\begin{array}{l}\text { Journal } \\
\text { name }\end{array}$ & $\begin{array}{l}\text { Reference } \\
\text { amount }\end{array}$ & $\begin{array}{l}\text { Subject } \\
\text { area }\end{array}$ \\
\hline Introduction & 17 & Trends Food Sci. Tech. & 3 & Food Science and Technology \\
\hline Food waste & 23 & $\begin{array}{l}\text { J. Clean. Prod. } \\
\text { J. Food Sci. } \\
\text { Polym. Rev. } \\
\text { Trends Food Sci. Tech. }\end{array}$ & $\begin{array}{l}2 \\
2 \\
2 \\
2\end{array}$ & $\begin{array}{l}\text { Green and Sustainable Science and Technology } \\
\text { Food Science and Technology } \\
\text { Polymer Science } \\
\text { Food Science and Technology }\end{array}$ \\
\hline Manufacture & 21 & $\begin{array}{l}\text { Food Hydrocolloid } \\
\text { Carbohyd. Polym. } \\
\text { Int. Food Res. J. }\end{array}$ & $\begin{array}{l}4 \\
3 \\
2\end{array}$ & $\begin{array}{l}\text { Chemistry, Applied } \\
\text { Chemistry, Applied } \\
\text { Food Science and Technology }\end{array}$ \\
\hline Shelf-life & 14 & $\begin{array}{l}\text { Food Hydrocolloid } \\
\text { J. Food Eng. }\end{array}$ & $\begin{array}{l}2 \\
2 \\
\end{array}$ & $\begin{array}{l}\text { Chemistry, Applied } \\
\text { Engineering, Chemical }\end{array}$ \\
\hline Environmental issues & 35 & $\begin{array}{l}\text { J. Clean. Prod. } \\
\text { Int. J. Life Cycle Assess. } \\
\text { Environ. Sci. Technol. } \\
\text { Food Res. Int }\end{array}$ & $\begin{array}{l}8 \\
6 \\
2 \\
2\end{array}$ & $\begin{array}{l}\text { Green and Sustainable Science and Technology } \\
\text { Engineering, Environmental } \\
\text { Engineering, Environmental } \\
\text { Food Science and Technology }\end{array}$ \\
\hline Socio-economic issues & 14 & Aquacult. Int. & 2 & Fisheries \\
\hline
\end{tabular}




\section{Food waste as a resource for seafood packaging: an interdisciplinary approach}

Food waste most commonly refers to edible food products which are intended for human consumption, but have instead been discarded, lost, degraded, or consumed by pests. It does not include the inedible or undesirable portions of foodstuffs. Food losses occur in production, storage, transport, and processing, which are the four stages of the value chain with the lowest returns. Food waste generated at the end of the supply chain, within retail and final consumption, represents greater costs and lost value when diverted away from human consumption; conversely, it is synonymous with higher value-chain potential. In highly developed countries, food waste is most prevalent during consumption (Licciardello, 2017; FAO 2011), while the causes of food losses and waste in low-income countries are mainly connected to financial, managerial, and technical limitations in harvesting techniques, storage, packaging, and marketing systems.

The percentage of food losses and waste of the edible parts varies between food groups across different points within the value chain (FAO, 2016; AschemannWitzel et al., 2017) and may also vary according to culture (Wang et al., 2017) . The proportion of purchased food wasted at the consumer level is especially high for fish and seafood in industrialized countries. High losses at the distribution level can be explained by high levels of deterioration occurring during fresh fish and seafood distribution (FAO, 2011).

The production of bio-waste in the EU amounts to more than 100 million tons each year, of which the majority derives from food processing industries (Ravindran and Jaiswal, 2016). In particular, fish and seafood processing generates large amounts of by-products, mainly consisting of shells and bones, which could represent around $50-70 \%$ of the original material content (Sayari et al., 2016). This bio-waste has a potential added-value, but research and innovation are needed to valorize it. The 
challenge is complex, affects a broad range of interconnected sectors, and requires a plurality of approaches (Mirabella et al., 2014).

Fish by-products contain relatively large concentrations of protein and fat. The most common products currently derived from fish by-products are collagen, gelatin, and biodiesel fuel (Trung, 2014). Well-known processes, based on successive steps of leaching of fish skin to remove water-soluble compounds, extraction of gelatin, cleansing, concentration, and drying, can give a yield of 125 tons of gelatin/time unit per 1 kiloton of fish skin. The world fish gelatin production is estimated to be in the range of 1.0-1.5 kiloton/year with a price of 10-20 USD $/ \mathrm{kg}$. Market opportunities exist to replace traditional bovine gelatins with fish gelatin due to safety concerns related to transferable spongiform encephalopathies (TSEs) and to replace porcine gelatins because of religious concerns. Market opportunities for fish gelatins and collagens are growing (Innovation Norway, 2014); they are often preferable to mammalian-derived products due to religious considerations as most can be used in both halal and kosher food (Rustad et al., 2011). Warm-water fish gelatins tend to have more similar properties to mammalian gelatins, although cold-water gelatins also have attractive properties for some food applications (Newton et al., 2014). The properties of fish gelatins vary between species and there are trade-offs between the different properties depending on the particular application.

Fish gelatin, obtained by collagen denaturation, is a highly available raw material for industrial applications, including the manufacture of films for food packaging. Residues from fish filleting represent up to $75 \%$ of harvested biomass, and approximately $30 \%$ of such residues consists of skin and bones with high collagen content (Newton et al., 2014; Zhang et al., 2016). The composition of gelatin is similar to that of the collagen from which it is prepared, predominantly containing proline (Pro) and hydroxyproline (Hyp) (Alfaro et al., 2015). In general, the imino acid content (Pro + Hyp) is lower in cold-water fish gelatins than in mammalian gelatins and, thus, these 
fish gelatins have lower melting points, which could be a benefit in the manufacture of fish gelatin-based products by thermo-mechanical processes due to lower energy consumption and cost, thereby increasing their commercial feasibility (Etxabide et al., 2016). Hyp content also varies depending on the treatment used to extract gelatin from collagen. This treatment can be carried out by basic (type B gelatin) or acid hydrolysis (type A gelatin) (Avena-Bustillos et al., 2006). Both type A and B gelatins show good film-forming ability and have been used to prepare food packaging films to protect food from drying and exposure to light and oxygen (Gómez-Guillén et al., 2009).

Processing of crustaceans also leads to large quantities of under-utilized byproducts. This bio-waste mainly consists of shells and heads, which account for about $35-40 \%$ of total wet weight (Trung and Phuong, 2012). Crustacean shells are a major source of chitin, which is the most abundant polysaccharide in nature after cellulose (Dutta et al., 2002). Chitin is a polysaccharide chemically similar to cellulose, in which the hydroxyl groups in the C2 position are replaced by acetamide groups. These functional groups make chitin a non-soluble polymer and limit their application. However, chitosan, obtained after chitin deacetylation, is soluble in acidic solutions, which enhances processability, as well as other functional properties, such as antimicrobial characteristics related to the presence of amine groups (Lim and Hudson, 2003). The antimicrobial activity of chitosan against a range of food-borne filamentous fungi, yeasts, and bacteria has attracted attention as a potential food preservative of natural origin (Rabea et al., 2003; No et al., 2007). The food preservation qualities of chitosan, along with its non-toxic nature, ability to chelate metals, and biodegradability are of interest for its incorporation into various food packaging strategies (Abdollahi et al., 2012).

\section{Manufacture of films and coatings based on fish gelatin and chitosan and their performance}




\subsection{Manufacturing processes}

Chitosan and gelatin films have been manufactured by solution casting and compression (Figure 3). On the one hand, solution casting involves the solubilization of the biopolymer in water under appropriate conditions of $\mathrm{pH}$ and temperature, followed by the drying process involving water evaporation. On the other hand, compression relies on the thermoplastic behavior that proteins and polysaccharides can display at low moisture contents (Hernández-Izquierdo and Krochta, 2008). At lab-scale, fish gelatin and chitosan films have been mainly prepared by solution casting due to the simplicity of the process and the use of water as the solvent. However, compression molding is less time-consuming and, thus, more appropriate for scaling-up the production. Recently, fish gelatin films (Chuaynukul et al., 2015) and chitosan films (Galvis-Sánchez et al., 2016) have been successfully produced by compression molding.

Once produced, the sealing ability of such films is an important characteristic for their application in materials used for making sachets, pouches, and bags. Heatsealing is widely used to join polymer films in the packaging industry. The seal resistance must be strong enough to keep food products (liquids or solids) inside the package without leakage. Tongnuanchan et al. (2016) have recently found that fish gelatin films are heat-sealable and, thus, they can be used for different food packaging formats.

The protective effect of hydrocolloids on food preservation can also be achieved by coatings applied to food surfaces (Figure 3). The characteristics of specific edible coatings affect performance, and this is also impacted by application methods, which influence coating thickness and, thus, its physicochemical properties and food preservation effects over time. Dipping is the most common application method at labscale due to its simplicity. However, the control of coating thickness and continuous 
production are two challenges when using this method (Zhong et al., 2014). Those drawbacks can be overcome by spraying methods, as these offer more uniform coatings (Andrade et al., 2012). For both methods, solution viscosity and application time are key parameters that influence coating thickness and, therefore, morphology, optical, mechanical, and barrier properties of the resulting coatings. The selection of the appropriate method and conditions affects not only the food preservation effect, but also the process efficiency and, thus, the production costs. Spraying allows deposit of thin coatings, reducing processing time in comparison with dipping and, thus, it opens a huge opportunity for continuous production on a commercial scale.

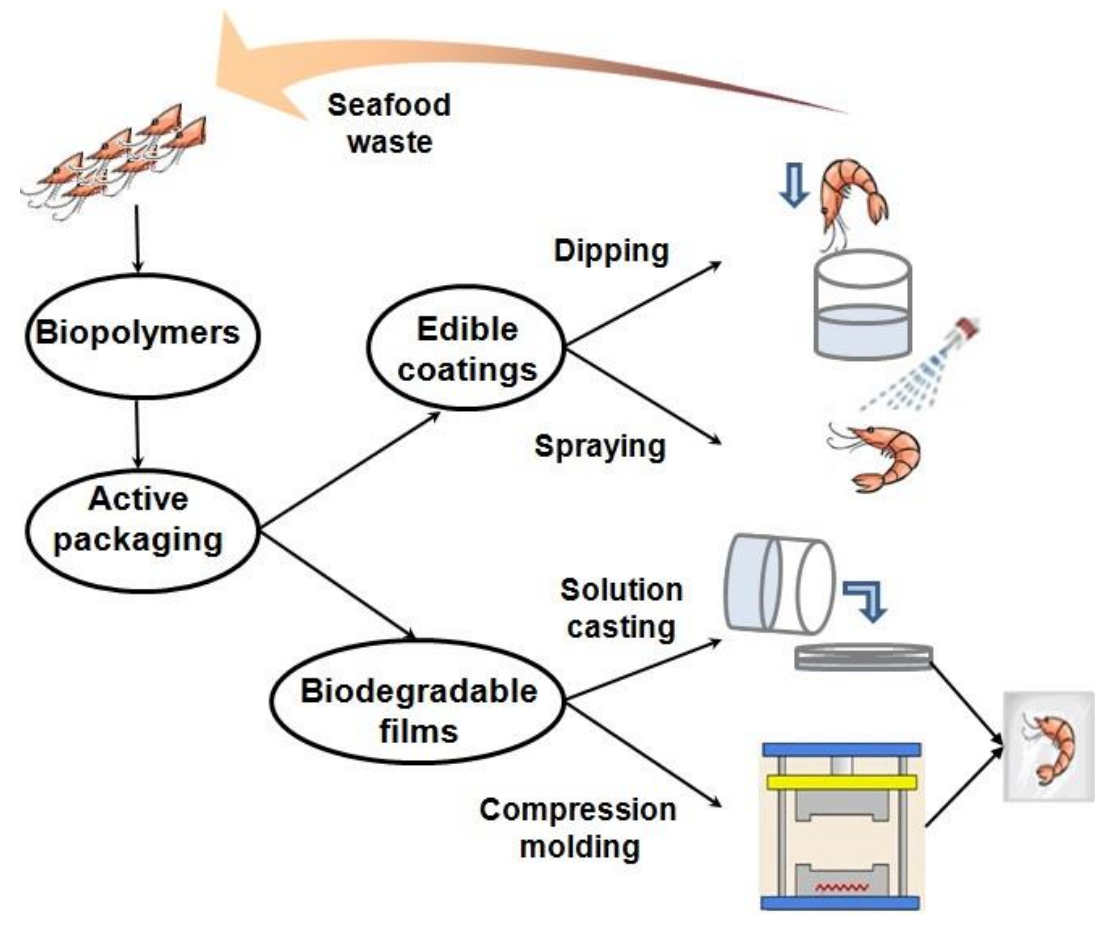

Fig.3. Manufacturing processes to develop active packaging, including edible coatings and biodegradable films.

\subsection{Functional properties}

Optical, barrier, and mechanical properties are the most relevant properties required for food packaging materials in order to preserve food quality (Atarés and Chiralt, 2016). Regarding optical properties, transparency and gloss of packaging films 
have a great impact on food appearance and, thus, on product acceptability by the consumer. The polymer network arrangement during film drying defines both internal and surface structure, and these determine optical properties (Villalobos et al., 2005). In this sense, image analyses, such as scanning electron microscopy (SEM) and atomic force microscopy (AFM) analyses, are required to correlate optical and structural parameters (Fabra et al., 2009). Films based on fish gelatin and chitosan are colorless and transparent, but they exhibit excellent barrier properties against UV light (Etxabide et al., 2015b; Hong et al., 2014; Samira et al., 2014). In addition to light barrier properties, appropriately formulated films and coatings should meet those aspects related to oxygen barrier to control oxygen exchange between food and the surrounding atmosphere, protecting food and delaying its deterioration by discoloration or texture softening.

Food packaging requires specific mechanical properties related to food quality during transportation, distribution, and storage. In this context, plasticizers represent the most common additives to improve mechanical performance. Demand for natural plasticizers to replace oil-based products is growing. Water is one of the natural plasticizers for hydrophilic polymers. As it is well-known, water increases free volume and so, material flexibility. Besides water, other bio-based plasticizers can be obtained from industrial by-products, providing available and sustainable resources (Garlapati et al., 2016). Glycerol, obtained as a by-product of the biodiesel industry, is the most used plasticizer in edible and biodegradable materials for food packaging applications, since it is approved as a food additive by the Food and Drug Administration (FDA) (Bocqué et al., 2016). Kaewprachu et al. (2016) have recently compared the mechanical performance of films based on proteins from different sources (both plant- and animalderived proteins) when using glycerol as plasticizer. They found that all films were uniform and transparent, but gelatin films exhibited higher tensile strength and elongation at break. In particular, fish gelatin films showed better mechanical 
performance than bovine gelatin films. This behavior was also reported by Rawdkuen et al. (2010). Since chitosan films present a higher tensile strength than gelatin films (Leceta et al., 2013a), and even higher than the values shown by commercial films (Farhan and Hani, 2017; Kaewprachu et al., 2016), blending fish gelatin and chitosan seems to be a potential alternative to synthetic polymers to obtain biocomposites with enhanced properties. Additionally, nanoclays such as montmorillonite (Nouri et al., 2018), cellulose nanofibers (Niu et al., 2018), and cellulose nanowhiskers (Bao et al., 2018) have been incorporated into coating-or film-forming formulations to reinforce the bionanocomposites.

\section{Shelf life extension and seafood quality related to active packaging}

Food shelf life is defined as the length of time that a food product in a container will remain in an acceptable condition for its use or application, under specific conditions of storage (Cruz-Romero and Kerry, 2011). Food shelf life is influenced by three factors: 1) The product characteristics, including formulation and processing parameters (intrinsic factors), 2) the properties of the package, and 3) the environment to which the product is exposed during distribution and storage (extrinsic factors) (Emblem, 2012a). Intrinsic factors include pH, water activity, enzymes, microorganisms, and concentration of reactive compounds. Many of these factors can be controlled by selection of raw materials and ingredients, as well as the choice of processing parameters. Extrinsic factors include temperature, relative humidity, light, total pressure, and partial pressure of different gases, as well as mechanical stresses including consumer handling. Many of these factors can affect the rates of deteriorative reactions that occur during the shelf life of a product.

When considering the preservation function of packaging, it is important to recognize that, whilst packaging can and does contribute to shelf life, it cannot overcome inherent product problems. If the product is unsafe or of poor quality at the 
point of packing, it is likely that the product will remain unsafe or of poor quality inside the pack. In order to determine the optimum packaging required to extend shelf life, it is necessary to define the product in terms of what will cause it to deteriorate, i.e. what is the spoilage mechanism. We then need to understand what process (if any) will be used to prevent/delay spoilage and the extent to which will affect the packaging used, and therefore determine its key properties (Emblem, 2012b).

Oxidation is one of the processes that causes food degradation, affecting both sensory and nutritional properties. The oxidation of highly unsaturated food lipids, such as fish and seafood, causes food quality deterioration, including off-odors, off-flavors, nutrition losses, and color or textural changes. These problems can significantly reduce consumer acceptability of food products, increase the deterioration rate of food, decrease the shelf life, and lead to food losses (López de Dicastillo et al., 2010; Tian et al., 2012). Synthetic antioxidants can be incorporated into food to prevent oxidation, but the use of such chemicals is losing favor and interest is growing in their replacement by natural additives. Hydrophilic films and coatings based on fish gelatin and/or chitosan provide a good barrier to oxygen due to their tightly packed hydrogen-bonded network (Bonilla et al., 2012). The use of antioxidant packaging is a novel approach in controlling oxidation and increasing the stability of oxidation-sensitive products, thereby prolonging the shelf life of food products (Etxabide et al., 2017).

Oxygen is responsible for many degradation processes in food, such as lipid oxidation, but also for microbial growth. Many types of bacteria typically found in fish and shellfish (e.g. Vibrio parahemolyticus) or found in processing settings (e.g Listeria monocytogenes) have been found to cause deterioration of food quality and safety (Enos-Berlage et al., 2005; Rajkowski 2009). In this challenging context, the development of materials with film-forming capacity that have antimicrobial properties has been increasingly demanded by the food industry (Vodnar et al., 2015). Since most fresh or processed products microbial contamination occurs at higher intensity on the 
product surface, the application of films or coatings on the food surface can be more efficient than the addition of antimicrobial additives directly in the foodstuff (Falguera et al., 2011). In this regard, key criteria for materials used for coating seafood products are sensory inertness and compatibility with the coated seafood product since food coatings should neither interfere with the flavor of the product nor alter any sensory properties. The combination of biopolymers, such as chitosan and gelatin, has been analyzed as antimicrobial packaging. The application of chitosan-gelatin film on fish has been found to delay or even prevent the growth of microorganisms, indicating the viability of these films for fish preservation (Gómez-Estaca et al., 2011). Chitosangelatin coatings have also been tested in some fishery products such as rainbow trout and Pacific white shrimp, both stored under refrigerated conditions (Farajzadeh et al., 2016; Nowzari et al., 2013). The positive effects of chitosan-gelatin coatings led to both oxidation and spoilage reduction, increasing food shelf-life. Therefore, it is clear that chitosan and/or gelatin coatings and films have potential for the control of food deterioration processes, increasing shelf life and safety; however, the impacts of using such products in terms of toxicological effects during handling or consumption also require attention.

\section{Health and safety aspects of active packaging from by-products}

Diverting waste, particularly animal by-products to food applications has various health and safety aspects regarding the suitability of those materials to be in contact with food. Legislation regarding those concerns vary regionally, but many draw on aspects of Codex Alimentarius and Hazard Analysis Critical Control Point (HACCP) approach, developed by the US Food and Drug Administration (FDA). More stringent legislation is enshrined in EU law under EU regulation regarding food, by-products and packaging where concerns about safe treatment of by-products (EC 2009, 2011a) and migration of substances in the packaging materials to food are addressed (EC 2004). However, of most concern perhaps is in relation to seafood allergy. Seafood allergy is a 
prevalent and potentially lethal condition (Thalayasingam and Lee 2015). Seafoodallergic individuals, when exposed to relevant allergens at levels that exceed their threshold for response, may suffer severe allergic reactions, even anaphylactic shock. Exposure to relevant levels of allergen and subsequent allergic reactions in seafoodallergic individuals usually occur by eating seafood or, less frequently, by direct skin contact or inhalation. Individual threshold levels may be low, and ingestion of food that contains traces of allergen, for example because it was prepared in a kitchen handling seafood, may result in allergic reactions in highly sensitized individuals. The use of seafood by-products carries the risk of contaminating foods with seafood allergens and allergic responses in seafood-allergic consumers. Any development and promotion of seafood by-product-based packaging and other products therefore requires risk assessment based on understanding the prevalence and sensitivity to seafood-based allergens, knowledge of relevant seafood allergens, testing of products made from seafood by-products for allergen levels, and assessment of the occurrence of allergic reactions in seafood-allergic individuals exposed to products made from seafood byproducts (FAO, 2014).

The prevalence of seafood allergy, namely the sensitization and occurrence of allergic reactions to fish and shellfish, is estimated to be up to $5 \%$ in the human population and may be increasing (Woo and Bahna, 2011). Regarding allergology, the most relevant shellfish are shrimps, crabs, lobsters, clams, oysters, and mussels. Shellfish allergy often develops in early childhood and is usually persistent. Allergic reactions vary from mild and local responses to life-threatening anaphylactic reactions. The clinical signs and symptoms include flush, pruritus, angioedema, and urticaria; rhinitis and conjunctivitis; bronchospasm, cough, and dyspnea; nausea, diarrhea, emesis, and gastric pain and burning; and a decrease in blood pressure and shock (Lehrer et al., 2003). 
Shellfish allergens are mostly flesh-derived, but in shrimps, allergens are also reported from the shells (Khora, 2016). Tropomysin is the major shellfish allergen but several others have been identified including arginine kinase, myosin light chain, and sarcoplasmic binding protein in crustaceans as well as paramyosin, troponin, actine, amylase, and hemoyanin in mollusks (Khora 2016). These allergens are highly heatstable and biochemically stable. However, since the first step in chitin extraction is deproteinization, it might be expected that these compounds would be removed from chitin after this process. However, levels of shellfish allergens must be assessed and the reliability of their removal established; the most common analytical methods are western blotting, the radio allergo-sorbent test, enzyme-linked immunosorbent assay, mass spectrometry, and liquid chromatography-tandem mass spectrometry (Korte et al., 2016). Shellfish allergy is diagnosed based on the clinical history, oral provocation challenges, in vivo analysis of skin reactivity, and in vitro quantification of specific serum IgE (Barber and Kalicinsky, 2016). Based on these measures, patients can be advised on their levels of sensitization and risk for allergic reactions and measures to prevent and treat them (Moonessinghe et al., 2016). As abovementioned, since deproteinization is carried out, substances that cause allergies are expected to be removed. However, further research is needed since the lack of allergenic risks would potentially expand the use of such packaging. In addition to the allergenic risks, the environmental risks associated to the extraction of biopolymers from food processing waste must be considered in order to produce healthier and more sustainable packaging. Therefore, redirection of seafood processing wastes is likely to have significant impacts on the size and quality of waste streams and substitution for environmentally impactful synthetic products and these are now considered.

\section{Environmental benefits of the circular economy}

Life cycle assessment (LCA) has proven to be a powerful tool in measuring emissions throughout the production value chain of goods and services. Its main 
advantage is that it identifies areas of disproportionate impact within the chain that can then be acted upon without shifting the impact to other areas within the value chain. This is particularly pertinent for food packaging as some packaging may be less impacting to produce than another, but it may not offer the same degree of protection to the food, resulting in higher spoilage and, therefore, much higher environmental impact at other points within the value chain (Conte et al., 2015).

LCA can also be used to assess the consequences of commercial choices, such as switching to renewable energy from fossil fuels and the resulting environmental impact across a range of different categories. Most LCAs are termed attributional midpoint studies in that they classify the numerous emissions and resource use into categories that have the potential to do harm within the environment. The impact categories used in LCA are numerous and varied, with some being more applicable to certain industries than others. However, out of the many categories, those which are of relevance to food production are global warming potential (GWP), acidification potential $(A P)$, eutrophication potential (EP), ozone depletion potential (ODP), photochemical oxidation potential (POP), increasingly land use (LU), and consumptive water use (CWU) (Table 2). Fossil fuel use (FFU) may also be considered as important for packaging raw material extractions and other categories, such as various toxicity potentials, are also important in many LCAs, including packaging. While the effects of different greenhouse gases can be standardized to a single indicator, the effects on biodiversity of disposal of different packaging materials is more difficult to quantify and standardize. Therefore, although the implications of biodegradation of bio-based polymers, such as GWP, ODP, EP, and others, may be measured against conventional plastics, quantifying the hazards to wildlife of each are more difficult, especially in relation to trade-offs between marine and terrestrial ecosystems (Curran et al., 2011).

Table 2. The impact categories which are of relevance in food production.

\section{Environmental impact Impact category}




\begin{tabular}{ll}
\hline Damage to human health & $\begin{array}{l}\text { Global warming potential (GWP) } \\
\text { Ozone depletion potential (ODP) } \\
\text { Photochemical oxidation potential (POP) }\end{array}$ \\
\hline Damage to ecosystems & $\begin{array}{l}\text { Acidification potential (AP) } \\
\text { Eutrophication potential (EP) }\end{array}$ \\
\hline \multirow{2}{*}{ Damage to resources } & $\begin{array}{l}\text { Land use (LU) } \\
\text { Consumptive water use (CWU) } \\
\text { Fossil fuel use (FFU) }\end{array}$ \\
\hline
\end{tabular}

Europe is the second largest producer of plastics in the world after China with around a 40\% market share for packaging purposes (Plastics Europe, 2017). Incorrect disposal of non-biodegradable plastic packaging materials and bags have particularly been associated with negative effects on marine life (EC, 2011b). Although in developed countries common plastic packaging such as polypropylene (PP) (Humbert et al., 2009), polyethylene terephthalate (PET) (Shen et al., 2011), or low density polyethylene (LDPE) (Siracusa et al., 2014) may be recycled effectively, in Europe less than $30 \%$ of plastics are recycled, with the rest being sent to landfill sites or to energyrecovery plants (Plastics Europe, 2017). Furthermore, plastic packaging becomes more difficult to recycle if multiple layers of different plastics are used for improving barrier properties, for example (Diop et al., 2017). Persistence of plastic in the (particularly marine) environment has recently been highlighted as a significant issue (Worm et al 2017). Therefore biodegradable bioplastics, particularly ones which are biocompatible and non-harmful if digested such as chitosan films are of considerable interest.

Numerous LCA studies have been published regarding the manufacture of different packaging materials from both traditional petrochemical-derived materials and natural polymers, but only a few have looked at the implications of these materials on spoilage and the various trade-offs between spoilage of the food product, reduction of waste, and ability to recycle these materials. Although for packaging wastes, the quantity of plastics is generally lower than that of paper, plastics have generally posed a much greater challenge because of their lack of biodegradability, emissions concerned with their incineration (Bohlman, 2004; Vidal et al., 2007), or persistence in 
landfill sites or the wider environment (Günkaya and Banar, 2016). Conversely, whereas bio-based films may degrade readily (Günkaya and Banar, 2016), the composting or landfill of biodegradable polymers may result in greater GHG emissions, such as carbon dioxide and methane (Ingrao et al., 2015). According to Ferreira et al. (2014), landfill gas is approximately $50 \%$ each of $\mathrm{CO}_{2}$ and methane. While $\mathrm{CO}_{2}$ emissions are biogenic and considered as neutral, methane has a global warming equivalence 25 times higher than $\mathrm{CO}_{2}$ and may become a problem during degradation, particularly if anaerobic conditions are allowed to develop in poorly managed composting or landfill sites. Bio-based films also generally contribute more highly to land use (Leceta et al., 2013b; 2014) and water use (Hermann et al., 2010) for growing the crops from which the raw materials originated. Interestingly, few LCAs of bio-based films include either land or water consumption, considering the reliance of the raw materials on these resources compared to fossil fuel-derived materials. However, many biopolymers may receive environmental credits from redirecting wastes, where the raw materials originate from agricultural by-products.

Many LCAs focus on the various trade-offs between traditional plastics vs. biobased polymers from different aspects. Some of the studies are at a concept or pilot level only and do not include commercial-scale production techniques necessary for direct comparisons. Individual LCAs of bio-based packaging materials include polylactic acid (PLA) (Hermann et al., 2010; Ingrao et al., 2015; Madival et al., 2009), PLA and starch composites (Benetto et al., 2015; Vidal et al., 2007), pectin and maize starch (Günkaya and Banar, 2016), wheat gluten (Deng et al., 2013), polyhydroxyalkanoate (PHA) (Khoo et al., 2010), chitosan (Leceta et al., 2013b; 2014), soy protein (Leceta et al., 2014), and agar (Leceta et al., 2014). In most cases, including chitosan films (Leceta et al., 2013b), the impacts from biopolymer production, apart from land and water utilization, were better or comparable to conventional plastic except for PHA (Khoo et al., 2010) and pectin and maize starch (Günkaya and Banar, 
2016 ), where the biopolymer was considerably worse performing due to energyintensive processes during production. Considering chitosan films are made from waste materials, there are considerable advantages compared to some other bioplastics for which the raw material requires a dedicated industry or redirection from human food chains. This was borne out by Muñoz et al. (2018) that showed raw materials for chitosan were redirected from composting. In other circumstances, chitin may be redirected from shrimp meal. However, shrimp meal is poor nutritionally and better efficiencies can be obtained by separating the chitin for chitosan production and retaining the protein and lipid fractions for animal nutrition (Newton et al., 2014).

Biopolymers perform particularly well compared to plastics in toxicity impacts related to disposal by incineration. In many cases, studies focus only on the production and subsequent disposal of an equivalent quantity of packaging material (e.g. $1 \mathrm{~m}^{2}$ of film) with little focus on the performance of the packaging itself in reducing food waste (Wikström et al., 2016; 2014). In the case of chitosan (and other active) packaging, it performs a more complex function than standard plastic in terms of the added shelf life provided for the packaged product. It is important to factor this extra functionality into the environmental impact assessment in terms of avoided waste from the retailer and, potentially, the consumer (Wikström et al., 2016, 2014; Zhang et al., 2015). As chitosan film has already shown to perform well against standard plastic films, environmental benefits from avoided waste and the associated emissions of its disposal, at both the raw material supply end and at the retailer would be expected to add considerable benefits to this type of packaging. Although extension of shelf life of seafood using chitosan packaging has not been shown, directly applied chitosan coatings have been shown to considerably extend the shelf life of herring (Jeon et al., 2002), salmon (Sathivel, 2005), and mackerel (Wu et al., 2016). As the impacts associated with the food product vastly outweigh those of the packaging (Zhang et al., 2015), even minor shelf life extension will significantly reduce global emissions as consumption efficiencies are gained. Quantifying these reductions in impact is highly researchable. 
A WRAP (2015) report showed that considerable financial savings could be made through extending shelf life of food and that the greatest savings could be made on the most perishable goods, such as seafood, because of the proportionately greater time for sale or utilization within the home. Zhang et al. (2015) demonstrated that by using antimicrobial packaging, considerable environmental impact savings could be made by reducing wasted beef at the retailer by $1.8 \%$ because of the substantial impacts associated with beef production. In most livestock production, including aquaculture, the majority of environmental impacts occur throughout the feed production stage with little contribution from the actual farming system, processing, or packaging, although the embodied impact accumulates at every stage throughout the life cycle of the product up to and including disposal. Therefore, small reductions in food waste at and after the processing stage result in larger reductions in accumulated upstream impacts and, consequently, the performance of the packaging in terms of its ability to reduce food wastage is often of much more consequence than the impacts associated with manufacture of the packaging material itself (Williams et al., 2008; Wikström et al., 2014, 2016).

Considering the large quantities of waste highlighted above by Gustavson et al. (FAO, 2011), in developed nations at the retailer and consumer level, substantial environmental impact reductions could be made with better packaging technology. However, as the environmental footprint of a food item becomes lower, as with salmon (Pelletier et al., 2009) compared to beef (Pelletier et al., 2010), the relative importance of the packaging manufacture becomes higher compared to food waste savings (Wikström et al., 2014, 2016; Williams and Wikström, 2011).

It is important to note that, while food safety and quality aspects associated with reducing spoilage by utilizing active packaging are of importance, physical attributes related to consumer-friendly packaging can be critical. Wikström et al. (2014) pointed out that a high percentage of waste may occur in the household if the packaging is not 
easy to use and/or does not meet the consumption requirements of a wide range of demographic groups, from large families with young children, to frail and elderly people living on their own. Therefore, ease-of-use characteristics are important to maintain when developing shelf life extension technologies. Such factors include: being easy to open without spillage, ability to reseal to prevent contamination, drying, and other spoilage, and easy to empty (Wikström et al., 2014; Williams and Wikström, 2011). Although packaging may extend shelf life considerably, its effect on consumer behavior to reduce waste is of more importance and difficult to measure (Williams and Wikström, 2011), but as pointed out in the WRAP (2015) report, it is likely that consumers may be highly influenced by extended shelf life, particularly on more perishable goods.

\section{Discussion of socio-economic implications of a circular economy for seafood packaging}

An interdisciplinary approach to enhancing the circular economy around use of aquaculture by-products has been critical to this holistic analysis. A range of technical challenges that draw on knowledge related to polymer chemistry through to food processing and quality are of course central but there has also been a need to identify potential public health risks and, critically, to articulate the social and economic dimension (Figure 4). Reducing food losses, minimizing waste, and adding-value to fisheries (and aquaculture) output are highlighted as being of critical importance for humanity and the planet in the Sustainable Development Goals (SDGs) adopted under the United Nations' 2030 Agenda for Sustainable Development (UN, 2015). In support of the goal related to sustainable consumption and production patterns, two targets are of relevance, in particular target 12.3 and target 12.5 . 


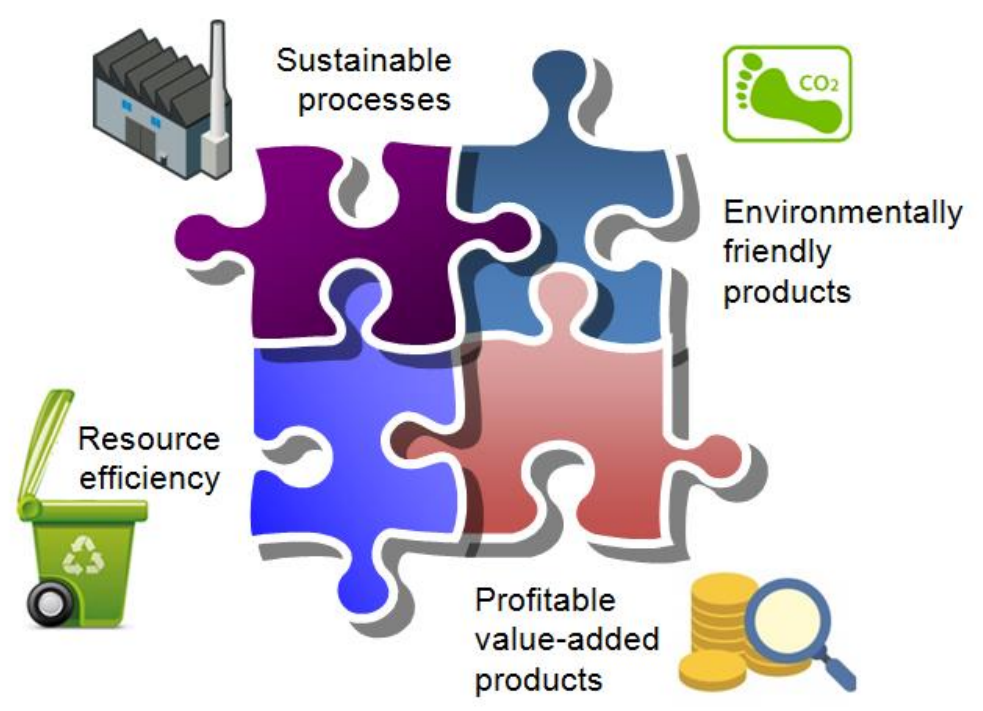

Fig.4. Assembly of the different aspects that must be considered when the development of novel packaging systems is addressed.

Target 12.3 relates to food waste at the retail level and consumption at home. Losses and waste of fish in developing countries mainly occurs in the postharvest stages of the value chain, due to poor handling and processing techniques, and lack of cold storage and ice, in part because small-scale producers are unable to access technology to maintain quality effectively. In developed countries a major proportion of food waste happens at the consumer level. For fish and seafood it has been estimated that in Europe about one-third of overall waste and losses in the fish and seafood value chain happen at the consumer-level (FAO, 2011). A reduction of fish waste at the consumer level through improved packaging and extending shelf life would therefore have potential to contribute to this target. A systematic assessment of opportunities for active packaging to counter unsustainable aspects of prevailing seafood product value chains could be conducted using the DPSIR (Driving forces-Pressures-State-ImpactsResponses) framework (Bunting, 2016).

Target 12.5 is about waste and losses along production and distribution chains. The large observed levels of by-product generated by the fish and seafood processing sector result in significant amounts of waste, when considering that in 2014 globally, 
capture fisheries and aquaculture together supplied about 167 million tons of fish, of which about $88 \%$ was utilized for human consumption. Of the latter, $54 \%$ (equal to 79 million tons) was supplied to consumers in different processed forms, and in Europe and North America this was as high as two-thirds of total fish for human consumption (FAO, 2016). The logistical challenges of adding enough value to processing byproducts in undeveloped markets are such that much still becomes waste. Enhancing the value of fisheries value chains would therefore have potential to contribute to end hunger, achieve food security and improved nutrition, and promote sustainable agriculture (UN, 2015).

When considering the social and economic costs and benefits of transforming fish by-products into packaging material, it should be noted that definitions of food losses and waste are not always straightforward, and what is edible also varies across contexts and time (Rutten, 2013). In addition, it depends on the reference frame of the analysis, as from a food security perspective biofuels, feed, and other non-food uses of resources intended for human consumption are considered a loss, while from a perspective of economics and value added they are not (Rutten, 2013). Who benefits from adopting alternative packaging solutions will also not be spread evenly or equitably across product value chains. Consequently, development of new techniques and packaging solutions should ideally occur in collaboration with value chain actors and be responsive to consumer needs and expectations. Approaches to engaging with stakeholders to understand their different perspectives, and challenge people to reevaluate their knowledge and perceptions, can include focus groups, product testing, and stakeholder Delphi assessments (Bunting, 2008; 2010).

Appropriate safeguards must be devised to ensure there are no adverse social impacts associated with changing packaging solutions. These impacts could come from three sources. First, diverting edible parts of fish away from consumption by the poor. In Bangladesh, for example, it has been shown that prawn heads and legs, 
removed as by-products during processing, are used for direct consumption (Ahmed et al., 2010). Second, diverting materials away from local processing industries may disadvantage poor and marginal groups employed in such activities. Value-added items produced from such by-products (e.g. pastes and sauces) can in turn contribute to the nutrition and food security of those directly involved and also communities not involved in aquaculture or fisheries (Plews-Ogan, 2013). Third, by-products may be diverted away from processing into formulated feed for fish, livestock, or poultry, thus affecting feed security indirectly (Anh et al., 2011; Muir, 2013).

There is circumstantial evidence that seafood by-product-derived packaging would find favor in the market place. Trends in corporate social responsibility (CSR) are strongly towards reduction in environmental impact in food processing and retail and food service sectors. Evidence shows that some seafood consumers have an interest in buying more environmentally friendly fish and that a significant portion of consumers is willing to pay more for it (Honkanen and Olsen, 2009; Olesen et al., 2010). Beneficial attributes of active packaging derived from seafood by-products may encourage consumers to seek out such products and to pay a premium for them. In markets where environmental certification is already well accepted, inclusion under existing schemes may be an efficient means to ensure that sustainable seafood packaging is adopted as a core element of broader assurance protocols. Alternatively, seafood brands and multiple retailers could invest in awareness-raising and labelling to communicate the benefits of sustainable packaging to consumers.

Whilst a novel type of active packaging may be technologically possible and environmentally beneficial, the packaging must also be commercially acceptable to those stakeholders in the distribution channel who effectively control access to end consumers, namely retailers, wholesalers, and food service providers. Organized forms of retailing, whether through multiple chains or affiliated networks, control increasing shares of product markets, store numbers, and floor-space in all parts of the world. 
This concentrates buying power and decision-making into fewer nodes, therefore acceptance by these stakeholders is crucial to the adoption of any form of packaging innovation. Mainstream grocery retailers, in general terms, operate a high volume/low margin business model, therefore incremental gains in cost reduction or increasing sales value are attractive, especially when the scale of the overall business is taken into account. Gains associated with high value/high margin product, such as shellfish, are particularly attractive.

However, retailers are notoriously cautious and are late adopters of technologybased food innovation (Esbjerg et al., 2016), particularly if they feel there is any risk or potential risk to their established customer franchise. Consumers eat food not packaging, therefore most retailer reluctance relates to new food production techniques where it is feared that customers do not understand or appreciate the technology concerned. However, consumers also have expectations and exhibit routine norms of behavior relating to packaging and product presentation. These need to be taken into account. Concerns have been expressed that packaging-related benefits can raise customer concerns if accepted norms are breached, for example, if shelf life is deemed to be too long and not "natural" (i.e. beyond the assumed/accepted norm).

Communication with customers in terms and language that they understand is therefore important to raise awareness of any benefits and to encourage acceptance.

The benefits of novel packaging would, however, appear to positively align with a number of current agendas within the retail grocery industry. The broad CSR and waste agendas are growing in importance, not just through increased legal compliance, but also as a point of differentiation and in response to increased consumer interest and expectations. Additionally, the CSR agenda provides the opportunity for cost savings or cost transfer within the distribution channel. Cost savings may be most evident in terms of the potential for extended shelf life, reduced waste, and less handling of products including shelf replenishment (which incurs direct costs and can 
increase shrinkage and waste). A third consideration is the consumer facing benefits relating to product quality and waste reduction, although commercial issues concerning the attractiveness of the packaging, and its role in product presentation as both an item and a category on a shelf display, play an important role. These considerations, alongside the reassurance that any packaging meets legal requirements relating to health and safety and carries minimal risk from allergies, will be taken into account by channel stakeholders when deciding if to adopt. They are commercial considerations, not technological considerations.

As a basic requirement it would be important to label packaging as biodegradable. Currently no major sustainability seafood certifier has moved to incorporate packaging into its standards, but this may simply recognize the current availability of technologies. Such organizations have also shown interest in moving from production-centric standards to whole value chain sustainability recognizing whole product value and rewarding innovations through certification. Other food packaging such as Tetrapak has moved to more sustainable raw material sourcing strategies and sought to raise attention to this change in pack-level labeling.

Potential benefits of adopting biodegradable active packing will also depend on the means of disposal. Often this depends on the municipal authorities or private operators, and investment of public money to facilitate recycling may be needed. Inappropriate disposal to landfill sites, for example, may result in significant negative environmental impacts negating gains elsewhere across the product value chain. Even where appropriate recycling facilities exist, consumer behavior can dictate how effective such schemes are and appropriate awareness-raising and support mechanics could be critical in realizing the potential of sustainable seafood packaging. Conditions needed to facilitate the widespread and successful adoption of active and biodegradable seafood packaging could be assessed using the STEPS (social, technical, environmental, political, sustainability) framework. 
In sum, adding value to fish processing by-products may benefit processors financially as increased sales will enhance their revenue and waste disposal costs may be avoided. However, a critical analysis of the long-term total costs and benefits of producing such materials needs to be made.

\section{Conclusions and future prospects}

This review highlights the need for an inter-disciplinary approach to the development of active seafood packaging within a circular economy. Massive waste generated during seafood processing can be properly managed in order to obtain renewable and biodegradable raw materials. This management implies the use of environmentally friendly and cost-effective processes for the extraction of materials to ensure that the innovative biorefinery practices designed to add value to by-products contributes to the sustainable development of materials. Nowadays, the production of chitosan and fish gelatin has been scaled up and these materials are commercially available. Furthermore, some bioactive compounds can be separated after chitosan or gelatin extraction and can be incorporated into the film-forming formulations to produce packaging and extend food shelf life and reduce food losses. Although some attempts have been successfully carried out to manufacture films and coatings based on chitosan and/or gelatin, more research in this field is needed in order to scale-up production using the techniques employed by the industries dedicated to the production of the conventional plastics and, thus, to produce sustainable and profitable seafood packaging. From a global and interdisciplinary point of view, adoption of technical, environmental, economical, and social considerations is needed to ensure that well intended initiatives to instigate a circular economy have positive impacts on the development of active food packaging, thereby contributing to food security and nutrition.

\section{References}


Abdollahi, M., Rezaei, M., Farzi, G,. 2012. A novel active bionanocomposite film incorporating rosemary essential oil and nanoclay into chitosan. J. Food Eng. 111, 343350.

Ahmed, N., Allison, E.H., Muir, J.F., 2010. Rice fields to prawn farms: a blue revolution in southwest Bangladesh? Aquacult. Int. 8, 555-574.

Alfaro, A.T., Balbinot, E., Weber, C.I., Tonial, I.B., Machado-Lunkes, A. 2015. Fish gelatin: Characteristics, functional properties, applications and future potentials. Food Eng. Rev. 7, 33-44.

Andrade, R.D., Skurtys, O., Osorio, F.A., 2012. Atomizing spray systems for application of edible coatings. Compr. Rev. Food Sci. Food. Saf. 11, 323-337.

Anh, P.T., My Dieu, T.T,, Mol, A.P.J., Kroeze, C., Bush, S.R., 2011. Towards eco-agro industrial clusters in aquatic production: The case of shrimp processing in Vietnam. J. Clean. Prod. 19, 2107-2118.

Aschermann-Witzel, J., de Hooge, I.E., Normann, A., 2016. Consumer-related food waste: Role of food marketing and retailers and potential for action. J. Int. Food Agribus. Mark. 28, 271-285.

Aschemann-Witzel, J., de Hooge, I.E., Rohm, H., Normann, A., Bonzanini Bossle, M., Grønhøj, A., Oostindjer, M., 2017. Key characteristics and success factors of supply chain initiatives tackling consumer-related food waste - A multiple case study. J. Clean. Prod .155, 33-45.

Atarés, L., Chiralt, A., 2016. Essential oils as additives in biodegradable films and coatings for active food packaging. Trends Food Sci. Tech. 48, 51-62.

Avena-Bustillos, R.J., Olsen, C.W., Olson, D.A., Chiou, B., Yee, E., Bechtel, P.J., McHugh, T.H., 2006. Water vapour permeability of mammalian and fish gelatin films. J. Food Sci. 71, E202-E207. 
Bao, Y., Zhang, H., Luan, Q., Zheng, M., Tang, H., Huang, F., 2018. Fabrication of cellulose nanowhiskers reinforced chitosan-xylan nanocomposite films with antibacterial and antioxidant activities. Carbohyd. Polym. 184, 66-73.

Barber, C., Kalicinsky, C., 2016. A novel combination of an IgE mediated adult onset food allergy and a suspected mast cell activation syndrome presenting as anaphylaxis. Allergy Asthma Clin. Immunol. 12, 46.

Benetto, E., Jury, C., Igos, E., Carton, J., Hild, P., Vergne, C., Di Martino, J., 2015. Using atmospheric plasma to design multilayer film from polylactic acid and thermoplastic starch: A screening life cycle assessment. J. Clean. Prod. 87, 953-960. Bocqué, M., Voirin, C., Lapinte, V., Caillol, S., Robin, J.J., 2016. Petro-based and biobased plasticizers: Chemical structures to plasticizing properties. J. Polym. Sci. Pol. Chem. 54, 11-33.

Bohlman, G.M., 2004. Biodegradable packaging life-cycle assessment. Environ. Prog. 23, 342-346.

Bonilla, J., Atarés, L., Vargas, M., Chiralt, A., 2012. Edible films and coatings to prevent the detrimental effect of oxygen on food quality: Possibilities and limitations. J. Food Eng. 110, 208-213.

Bowen, K.J., Friel, S., 2012. Climate change adaptation: Where does global health fit in the agenda? Global Health 8, 1-7.

Bunting, S.W., 2010. Assessing the stakeholder Delphi for facilitating interactive participation and consensus building for sustainable aquaculture development. Soc. Natur. Resour. 23, 758-775.

Bunting, S.W., 2008. Horizontally integrated aquaculture development: Exploring consensus on constraints and opportunities with a stakeholder Delphi. Aquacult. Int. 16, 153-169. 
Bunting, S.W., Luo, S., Cai, K., Kundu, N., Lund, S., Mishra, R., Ray, D., Smith, K.G., Sugden, F., 2016. Integrated action planning for biodiversity conservation and sustainable use of highland aquatic resources: evaluating outcomes for the Beijiang river, China. J. Environ. Plan. Manage. 59, 1580-1609.

Chuaynukul, K., Prodpran, T., Benjakul, S., 2015. Properties of thermo-compression molded bovine and fish gelatin films as influenced by resin preparation condition. Int. Food Res. J. 22, 1095-1102.

Conte, A., Cappelletti, G.M., Nicoletti, G.M., Russo, C., Del Nobile, M.A., 2015. Environmental implications of food loss probability in packaging design. Food Res. Int. $78,11-17$.

Cruz-Romero, M., Kerry, J.P., 2011. Packaging of cooked meat and muscle-based, convenience-style processed foods, in: Kerry, J.P., Kerry, J.F. (Eds.), Processed Meats: Improving Safety, Nutrition and Quality. Woodhead Publishing, Cambridge, pp. 666-705.

Curran, M., de Baan, L., De Schryver, A.M., van Zelm, R., Hellweg, S., Koellner, T., Sonnemann, G., Huijbregts, M.A.J., 2011. Toward meaningful end points of biodiversity in Life Cycle Assessment. Environ. Sci. Technol. 45, 70-79.

Deng, Y., Achten, W.M.J., Van Acker, K., Duflou, J.R., 2013. Life cycle assessment of wheat gluten powder and derived packaging film. Biofuels Bioprod. Bioref. 7, 429-458.

Diop, C.I.K., Lavoie, J.M., Huneault, M.A., 2017. Separation and reuse of multilayer food packaging in cellulose reinforced polyethylene composites. Waste Biomass Valorization 8, 85-93.

Dutta, P.K., Ravikumar, M.N.V., Dutta, J. 2002. Chitin and chitosan for versatile applications. Polym. Rev. 42, 307-354. 
Emblem, A., 2012a. Plastic properties for packaging materials, in: Emblem, A., Emblem, H. (Eds.). Packaging technology: Fundamentals, materials and processes. Woodhead Publishing, Cambridge, pp. 287-309.

Emblem, A., 2012b. Packaging functions, in: Emblem, A., Emblem, H. (Eds.). Packaging technology: Fundamentals, materials and processes. Woodhead Publishing, Cambridge, pp. 24-49.

Enos-Berlage, J.L., Guvener, Z.T., Keenan, C.E., McCarter, L.L., 2005. Genetic determinants of biofilm development of opaque and translucent Vibrio parahaemolyticus. Mol. Microbiol. 55, 1160-1182.

Esbjerg, L., Burt, S., Pearse, H., Glanz-CXhanos, V., 2016. Retailers and technologydriven innovation in the food sector. Br. Food. J. 118, 1370-1383.

Etxabide, A., Guerrero, P., de la Caba, K., 2016. A novel approach to manufacture porous biocomposites using extrusion and injection moulding. Eur. Polym. J. 82, 324333.

Etxabide, A., Urdanpilleta, M., Guerrero, P., de la Caba, K., 2015b. Effects of crosslinking in nanostructure and physicochemical properties of fish gelatins for bioapplications. React. Funct. Polym. 94, 55-62.

Etxabide, A., Uranga, J., Guerrero, P., de la Caba, K., 2017. Development of active gelatin films by means of valorisation of food processing waste: A review. Food Hydrocolloid 68, 192-198.

European Commission (EC) 2004. Regulation (EC) No 1935/2004 of the European Parliament and of the Council of 27 October 2004 on materials and articles intended to come into contact with food and repealing Directives 80/590/EEC and 89/109/EEC https://eur-lex.europa.eu/legalcontent/EN/TXT/PDF/?uri=CELEX:32004R1935\&from=en. 14pp. 
European Commission (EC) 2009. Regulation (EC) No 1069/2009 of the European Parliament and of the Council of 21 October 2009 Laying Down Health Rules as Regards Animal By-Products and Derived Products Not Intended for Human Consumption and Repealing Regulation (EC) No 1774/2002 (Animal by-products Regulation). http://eur-lex.europa.eu/legalcontent/EN/TXT/PDF/?uri=CELEX:32009R1069andfrom=EN. 33pp.

European Commission (EC) 2011a. Commission Regulation (EU) No 142/2011 of 25 February 2011 Implementing Regulation (EC) No 1069/2009 of the European Parliament and of the Council Laying Down Health Rules as Regards Animal ByProducts and Derived Products Not Intended for Human Consumption and Implementing Council Directive 97/78/EC as Regards Certain Samples and Items Exempt from Veterinary Checks at the Border Under that Directive. http://faolex.fao.org/docs/pdf/eur109216.pdf. 252pp European Commision (EC). 2011b. Plastic waste: ecological and human health impacts. Available from:

http://ec.europa.eu/environment/integration/research/newsalert/pdf/IR1_en.pdf. Accessed 2018 May 19.

Fabra, M.J., Talens, P., Chiralt, A., 2009. Microstructure and optical properties of sodium caseinate films containing oleic acid-beeswax mixtures. Food Hydrocolloid 23, 676-683.

Fader, M., Gerten, D., Krause, M., Lucht, W., Cramer, W., 2013. Spatial decoupling of agricultural production and consumption: quantifying dependences of countries on food imports due to domestic land and water constraints. Environ. Res. Lett. 8, 014046.

Falguera, V., Quintero, J.P., Jiménez, A., Aldemar Muñoz, J., Ibarz, A., 2011. Edible films and coatings: Structures, active functions and trends in their use. Trends Food Sci. Tech. 22, 292-303. 
Farajzadeh, F., Motamedzadegan, A., Shahidi, S.A., Hamzeh, S., 2016. The effects of chitosan-gelatin coating on the quality of shrimp (Litopenaeus vannamei) under refrigerated conditions. Food Control 67, 163-170.

Farhan, A., Hani, N.M., 2017. Characterization of edible packaging films based on semi-refined kappa-carrageenan plasticized with glycerol and sorbitol. Food Hydrocolloid 64, 48-58.

Ferrari, R., 2015. Writing narrative style literature reviews. Medical Writing 24, 230-235.

Ferreira, S., Cabral, M., da Cruz, N.F., Simoes, P., Marques, R.C., 2014. Life cycle assessment of a packaging waste recycling system in Portugal. Waste Manage. 34, $1725-1735$

Food and Agriculture Organization of the United Nations (FAO). 2014. Assessment and management of seafood safety and quality. Available from: http://www.fao.org/3/ai3215e.pdf. Accessed 2018 May 19.

Food and Agriculture Organization of the United Nations (FAO). 2015. Consumers' concerns and external drivers in food markets. Available from: http://www.fao.org/3/ai4939e.pdf. Accessed 2018 May 19.

Food and Agriculture Organization of the United Nations (FAO). 2011. Global Food losses and food waste. Available from:

http://www.fao.org/docrep/014/mb060e/mb060e.pdf. Accessed 2018 May 19.

Food and Agriculture Organization of the United Nations (FAO). 2016. The State of World Fisheries and Aquaculture 2016. Available from: http://www.fao.org/3/ai5555e.pdf. Accessed 2018 May 19.

Fraser, E., Legwegoh, A., Krishna, K.C., CoDyre, M., Dias, G., Hazen, S., Johnson, R., Martin, R., Ohberg, L., Sethuratnam, S., Sneyd, L., Smithers, J., Van Acker, R., Vansteenkiste, J., Wittman, H., Yada, R., 2016. Biotechnology or organic? Extensive or 
intensive? Global or local? A critical review of potential pathways to resolve the global food crisis. Trends Food Sci. Technol. 48, 78-87.

Future Market Insights. 2017. Protective Packaging Market: Global Industry Analysis and Opportunity Assessment 2015-2025. Available from:

http://www.futuremarketinsights.com/reports/protective-packaging-market. Accessed 2018 May 19.

Galvis-Sánchez, A.C., Sousa, A.M.M., Hilliou, L., Gonçalves, M.P., Souza, H.K.S., 2016. Thermo-compression molding of chitosan with a deep eutectic mixture for biofilms development. Green Chem. 18, 1571-1580.

Garlapati, V.K., Shankar, U., Budhiraja, A., 2016. Bioconversion technologies of crude glycerol to value added industrial products. Biotechnol. Rep. 9, 9-14.

Genovese, A., Acquaye, A.A., Figueroa, A., Koh, S.C.L., 2017. Sustainable supply chain management and the transition towards a circular economy: Evidence and some applications. Omega 66, 344-357.

Gómez-Estaca, J., Gómez-Guillén, M.C., Fernández-Martín, F., Montero, P., 2011. Effects of gelatin origin, bovine-hide and tuna-skin, on the properties of compound gelatin-chitosan films. Food Hydrocolloid 25, 1461-1469.

Gómez-Guillén, M.C., Pérez-Mateos, M., Gómez-Estaca, J., López-Caballero, E., Giménez, B., Montero, P., 2009. Fish gelatin: a renewable material for developing active biodegradable films. Trends Food Sci. Tech. 20, 3-16.

Günkaya, Z., Banar, M., 2016. An environmental comparison of biocomposite film based on orange peel-derived pectin jelly-corn starch and LDPE film: LCA and biodegradability. Int. J. Life Cycle Assess. 21, 465-475. 
Hermann, B.G., Blok, K.I., Patel, M.K., 2010. Twisting biomaterials around your little finger: Environmental impacts of bio-based wrappings. Int. J. Life Cycle Assess. 15, 346-358.

Hernández-Izquierdo, V.M., Krochta, J.M., 2008. Thermoplastic processing of proteins for film formation. J. Food Sci. 73, R30-R39.

Hong, P.K., Gottardi, D., Ndagijimana, M., Betti, M., 2014. Glycation and transglutaminase mediated glycosylation on fish gelatin peptides with glucosamine enhance bioactivity. Food Chem. 142, 285-293.

Honkanen, P., Olsen, S.O., 2009. Environmental and animal welfare issues in food choice: The case of farmed fish. Brit. Food J. 111, 293-309.

Humbert, S., Rossi, V., Margni, M., Jolliet, O., Loerincik, Y., 2009. Life cycle assessment of two baby food packaging alternatives: Glass jars vs. plastic pots. Int. J. Life Cycle Assess. 14, 95-106.

Ingrao, C., Tricase, C., Cholewa-Wójcik, A., Kawecka, A., Rana, R., Siracusa, V., 2015. Polylactic acid trays for fresh-food packaging: A carbon footprint assessment. Sci. Total Environ. 537, 385-398.

Innovation Norway. 2014. Market Opportunities for Norwegian technology providers and processors. Available from: http://akvarena.no/uploads/Ekstern\%20informasjon/Catfish_by-product.pdf. Accessed 2018 May 19.

Janssen, M.A., Schoon, M.L., Ke, W., Börner, K., 2006. Scholarly networks on resilience, vulnerability and adaptation within the human dimensions of global environmental change. Global Environmental Change 16, 240-252.

Jeon, Y.J., Kamil, J.Y.V.A., Shahidi, F., 2002. Chitosan as an edible invisible film for quality preservation of herring and Atlantic cod. J. Agr. Food Chem. 50, 5167-5178. 
Jurgilevich, A., Birge, T., Kentala-Lehtonen, J., Korhonen-Kurki, K., Pietikäinen, J., Saikku, L., Schösler, H., 2016. Transition towards circular economy in the food system. Sustainability $8,1-14$.

Kaewprachu, P., Osako, K., Benjakul, S., Tongdeesoontorn, W., Rawdkuen, S., 2016. Biodegradable protein-based films and their properties: A comparative study. Packag. Technol. Sci. 29, 77-90.

Kearney, J., 2010. Food consumption trends and drivers. Phil. Trans. R. Soc. B 365, 2793-2807.

Khoo, H.H., Tan, R.B.H., Chng, K.W.L., 2010. Environmental impacts of conventional plastic and bio-based carrier bags. Int. J. Life Cycle Assess. 15, 284-293.

Khora, S.S., 2016. Seafood-associated shellfish allergy: A comprehensive review. Immunol. Invest. 45, 504-530.

Kim, D., Seo, J., 2018. A review: Breathable films for packaging applications. Trends Food Sci. Technol. 76, 15-27.

Korte, R., Monneuse, J.M., Gemrot, E., Metton, I., Humpf, H.U., Brockmeyer, J., 2016. New high -performance liquid chromatography coupled mass spectrometry method for the detection of lobster and shrimp allergens in food samples via multiple reaction monitoring and multiple reaction monitoring cubed. J. Agr. Food Chem. 64, 6219-6227. Laso, J., Margallo, M., Fullan, P., Bala, A., Gazulla, C., Irabien, A., Aldaco, R., 2016. Waste management under a life cycle approach as a tool for a circular economy in the canned anchovy industry. Waste Manage. Res. 34, 724-733.

Leceta, I., Etxabide, A., Cabezudo, S., de la Caba, K., Guerrero, P., 2014. Bio-based films prepared with by-products and wastes: Environmental assessment. J. Clean. Prod. 64, 218-227. 
Leceta, I., Guerrero, P., Cabezudo, S., de la Caba, K., 2013b. Environmental assessment of chitosan-based films. J. Clean. Prod. 41, 312-318.

Leceta, I., Guerrero, P., de la Caba, K., 2013a. Functional properties of chitosan-based films. Carbohyd. Polym. 93, 339-346.

Lehrer, S.B., Ayuso, R., Reese, G., 2003. Seafood allergy and allergens: A review. Mar. Biotechnol. 5, 339-348.

Licciardello, F., 2017. Packaging, blessing in disguise. Review on its diverse contribution to food sustainability. Trends Food Sci. Technol. 65, 32-39.

Lim, S.H., Hudson, S.M., 2003. Review of chitosan and its derivatives as antimicrobial agents. Polym. Rev. 43, 223-269.

López de Dicastillo, C., Alonso, J.N., Catalá, R., Gavara, R., Hernández-Muñoz, P., 2010. Improving the antioxidant protection of packaged food by incorporating natural flavanoids into ethylene-vinyl alcohol copolymer (EVOH) films. J. Food Eng. 104, 380386.

Madival, S., Auras, R., Singh, S.P., Narayan, R., 2009. Assessment of the environmental profile of PLA, PET and PS clamshell containers using LCA methodology. J. Clean. Prod. 17, 1183-1194.

Miravella, N., Castellani, V., Sala, S., 2014. Current options for the valorization of food manufacturing waste. J. Clean. Prod. 65, 28-41.

Moonesinghe, H., Mackenzie, H., Venter, C., Kilburn, S., Turner, P., Weir, K., Dean, T., 2016. Prevalence of fish and shellfish allergy: A systematic review. Ann. Allerg. Asthma Im. 117, 264-272.

Muir, J., 2013. Fish, feeds and food security. Anim. Front. 3, 28-34. 
Muñoz, I., Rodríguez, C., Gillet, D., Moerschbacher, B.M., 2018. Life cycle assessment of chitosan production in India and Europe. Int. J. Life Cycle Assess. 23, 1151-1160.

Newton, R., Telfer, T., Little, D., 2014. Perspectives on the utilization of aquaculture coproduct in Europe and Asia: Prospects for value addition and improved resource efficiency. Crit. Rev. Food Sci. 54, 495-510.

Niu, X., Liu, Y., Song, Y., Han, J., Pan, H., 2018. Rosin modified cellulose nanofiber as a reinforcing and co-antimicrobial agents in polylactic acid /chitosan composite film for food packaging. Carbohyd. Polym. 183, 102-109.

No, K.K., Meyers, S.P., Prinyawiwatkul, W., Xu, Z., 2007. Applications of chitosan for improvement of quality and shelf life of food: a review. J. Food Sci. 72, 87-100.

Nouri, A., Yaraki, M.T., Ghorbanpour, M., Agarwal, S., Gupta, V.K., 2018. Enhanced antibacterial effect of chitosan film using montmorillonite/CuO naonocomposite. Int. J. Biol. Macromol. 109, 1219-1231.

Nowzari, F., Shábanpour, B., Ojagh, S.M., 2013. Comparison of chitosan-gelatin composite and bilayer coating and film effect on the quality of refrigerated rainbow trout. Food Chem. 141, 1667-1672.

Olesen, I., Alfnes, F., Rora, M.B., Kolstad, K., 2010. Eliciting consumers' willingness to pay for organic and welfare-labelled salmon in a non-hypothetical choice experiment. Livest. Sci. 127, 218-226.

Pelletier, N., Pirog, R., Rasmussen, R., 2010. Comparative life cycle environmental impacts of three beef production strategies in the Upper Midwestern United States. Agr. Syst. 103, 380-389.

Pelletier, N., Tyedmers, P., Sonesson, U., Scholz, A., Ziegler, F., Flysjo, A., Cancino, B., Silverman, H., 2009. Not all salmon are created equal: Life cycle assessment (LCA) of global salmon farming systems. Environ. Sci. Technol. 43, 8730-8736. 
Perrot, N., De Vries, H., Lutton, E., van Mil, H.G.J., Donner, M., Tonda, A., Martin, S., Alvarez, I., Bourgine, P., van der Linden, E., Axelos, M.A.V., 2016. Some remarks on computational approaches toward sustainable complex agri-food systems. Trends Food Sci. Tech. 48, 88-101.

Plastics Europe. 2017. Plastics - the Facts 2017. Available from:

http://www.plasticseurope.org/en/resources/publications/plastics-facts-2017. Accessed 2018 May 19.

Plews-Ogan, E.J., 2013. Eat until you're full: the pursuit of autonomy and health through the adoption of organic agriculture in Mae Ta, Thailand. Available from: http://openworks.wooster.edu/independentstudy/1145. Accessed 2018 May 19.

Rabea, E.I., Badawy, M.E.T., Stevens, C.V., Smagghe, G., Steurbaut, W. 2003. Chitosan as antimicrobial agent: applications and mode of action. Biomacromolecules 4, 1457-1465.

Rajkowski, K.T., 2009. Biofilms in fish processing, in: Fratamico, P.M., Annous, B.A., Gunther, N.W. (Eds.). Biofilms in the food and beverage industries. Woodhead Publishing, Cambridge, pp. 499-516.

Ravindran, R., Jaiswal, A.K., 2016. Exploitation of food industry waste for high-value products. Trends Biotechnol. 34, 58-69.

Rawdkuen, S., Sai-Ut, S., Benjakul, S., 2010. Properties of gelatin films from giant catfish skin and bovine bone: a comparative study. Eur. Food Res. Technol. 231, 907916.

Rustad, T., Storro, I., Slizyte, R., 2011. Possibilities for the utilisation of marine byproducts. Int. J. Food Sci. Tech. 46, 2001-2014. 
Rutten, M.M., 2013. What economic theory tell us about the impacts of reducing food losses and/or waste: Implications for research, policy and practise. Agr. Food Secur. 2, $1-13$.

Samira, S., Thuan-Chew, T.C., Azhar, M.E., 2014. Effect of ribose-induced Maillard reaction on physical and mechanical properties of bovine gelatin films prepared by oven drying. Int. Food Res. J. 2, 269-276.

Sathivel, S., 2005. Chitosan and protein coatings affect yield, moisture loss, and lipid oxidation of pink salmon (Oncorhynchus gorbuscha) fillets during frozen storage. J. Food Sci. 70, E455-E459.

Sayari, N., Sila, A., Abdelmalek, B.E., Abdallah, R.B., Ellouz-Chaabouni, S., Bougatef, A., Balti, R., 2016. Chitin and chitosan from the Norway lobster by-products: antimicrobial and anti-proliferative activities. Int. J. Biol. Macromol. 87, 163-171. Shen, L., Nieuwlaar, E., Worrell, E., Patel, M.K., 2011. Life cycle energy and GHG emissions of PET recycling: Change-oriented effects. Int. J. Life Cycle Assess. 16, 522536.

Simoes, J.S., Mársico, E.T., da Cruz, A.G., Queiroz de Freitas, M., Loro, D.H., ConteJunior, C.A., 2015. Effect of sustainability information on consumers' liking of freshwater prawn (Macrobrachium rosenbergii). J. Sci. Food Agric. 95, 3160-3164.

Siracusa, V., Ingrao, C., Lo Giudice, A., Mbohwa, C., Dalla Rosa, M., 2014. Environmental assessment of a multilayer polymer bag for food packaging and preservation: An LCA approach. Food Res. Int. 62, 151-161.

Stahel, W.R., 2016. Circular economy. Nature 531, 435-438.

Thalayasingam, M., Lee, B.W., 2015. Fish and shellfish allergy. Chem. Immunol. Allerg. 101, 152-161. 
Tian, F., Decker, E.A., Goddard, J.M., 2012. Control of lipid oxidation by nonmigratory active packaging films prepared by photoinitiated graft polymerization. J. Agr. Food Chem. 60, 2046-2052.

Tongnuanchan, P., Benjakul, S., Prodpran, T., Pisuchpen, S., Osako, K., 2016. Mechanical, thermal and heat sealing properties of fish skin gelatin film containing palm oil and basil essential oil with different surfactants. Food Hydrocolloid 56, 93-107.

Trung, T.S., 2014. The innovative utilization of fishery by-products in Vietnam. Seminar on Improved utilization of fishery by-products as potential nutraceuticals and functional foods; Bangkok, Thailand, 25-29 October 2010. Taipei, Taiwan: Food and Fertilizer Technology Center.

Trung, T.S., Phuong, P.T.D., 2012. Bioactive Compounds from By-Products of Shrimp Processing Industry in Vietnam. J. Food Drug Anal. 20, 194-197.

United Nations (UN). 2015. Transforming our world: the 2030 agenda for sustainable development. Available from:

https://sustainabledevelopment.un.org/post2015/transformingourworld. Accessed 2018 May 19.

Vidal, R., Martínez, P., Mulet, E., González, R., López-Mesa, B., Fowler, P., Fang, J.M., 2007. Environmental assessment of biodegradable multilayer film derived from carbohydrate polymers. J. Polym. Environ. 15, 159-168.

Villalobos, R., Chanona, J., Hernández, P., Gutiérrez, G., Chiralt, A., 2005. Gloss and transparency of hydroxypropyl methylcellulose films containing surfactants as affected by their microstructure. Food Hydrocolloid 19, 53-61.

Vodnar, D.C., Pop, O.L., Dulf, F.V., Socaciu, C., 2015. Antimicrobial efficiency of edible films in food industry. Not. Bot. Horti. Agrobo. 43, 302-312. 
Wang, L., Liu, G., Liu, X., Liu, Y., Gao, J., Zhou, B., Gao, S., Cheng, S., 2017. The weight of unfinished plate: A survey based characterization of restaurant food waste in Chinese cities. Waste Manage. 66, 3-12.

Wikström, F., Williams, H., Venkatesh, G., 2016. The influence of packaging attributes on recycling and food waste behaviour - An environmental comparison of two packaging alternatives. J. Clean. Prod. 137, 895-902.

Wikström, F., Williams, H., Verghese, K., Clune, S., 2014. The influence of packaging attributes on consumer behaviour in food packaging life cycle assessment studies - A neglected topic. J. Clean. Prod. 73, 100-108.

Williams, H., Wikström, F., 2011. Environmental impact of packaging and food losses in a life cycle perspective: a comparative analysis of five food items. J. Clean. Prod. 24, 141-148.

Williams, H., Wikström, F., Löfgren, M., 2008. A life cycle perspective on environmental effects of customer focused packaging development. J. Clean. Prod. 16, 853-859.

Wilson, C.T., Harte, J., Almenar, E., 2018. Effects of sachet presence on consumer product perception and active packaging acceptability - A study of fresh-cut cantaloupe. LWT 92, 531-539.

Woo, C.K., Bahna, S.L., 2011. Not all shellfish "allergy" is allergy! Clin. Transl. Allergy $1,1-7$.

Worm, B., Lotze, H.K., Jubinville, I., Wilcox, C., Jambeck, J., 2017. Plastics as a persistent marine pollutant. Annu. Rev. Environ. Resour. 42, 1-26.

WRAP. 2015. Reducing food waste by extending product life. Available from: http://www.wrap.org.uk/sites/files/wrap/Product\%20Life\%20Report\%20Final_0.pdf. Accessed 2018 May 19. 
Wu, C., Li, Y., Wang, L., Hu, Y., Chen, J., Liu, D., Ye, X., 2016. Efficacy of chitosangallic acid coating on shelf extension of refrigerated pacific mackerel fillets. Food Bioprocess. Technol. 9, 675-685.

Zhang, H., Hortal, M., Dobon, A., Bermudez, J.M., Lara-Lledo, M., 2015. The effect of active packaging on minimizing food looses: Life cycle assessment (LCA) of essential oil component-enables packaging for fresh beef. Packag. Technol. Sci. 28, 761-774.

Zhang, Q., Wang, Q., Lv, S., Lu, J., Jiang, S., Regenstein, J.M., Lin, L., 2016.

Comparison of collagen and gelatin extracted from the skins of Nile tilapia (Oreochromis niloticus) and catfish (Ictalurus punctatus). Food Biosci. 13, 41-48.

Zhong, Y., Cavender, G., Zhao, Y., 2014. Investigation of different coating application methods on the performance of edible coating on Mozzarella cheese. LWT-Food Sci. Technol. 56, 1-8. 